\title{
Financial Leverage and SMEs Performance: Empirical Evidence from Donggala District, Indonesia
}

\author{
Rajindra \\ Faculty of Economic, Universitas Muhammadiyah Palu Indonesia; Email: indra.laraca@yahoo.com
}

\begin{abstract}
Doi:10.5901/mjss.2016.v7n6p87
\end{abstract}
\section{Abstract}

Great role of SMEs in economic development in Donggala district is mainly because this sector absorbs quite lot of resources which if managed proportionally it will be able to provide a multiplier effect that encourages the development of regions in Donggala significantly. The multiplier effect of SME sector is mainly derived from the vast number of business units as well as outstanding contributions to the creation of employment and sources of income, especially in rural areas and for rural households. To create these SMEs as a sector with a competitive advantage necessarily to understand the limitations of SMEs on which in terms of size and funding policy and the ability of their working capital, this may result in lower production capabilities and financial performance as a whole. This study aimed to analyze the influence of Financing and Working Capital Policy Against Financial Performance of Micro, Small and Medium Enterprises in Donggala. The population in this study were 1,752 SMEs, sampling is done by using Taro Yamane formula or formula slovin followed by the proportional method. The number of samples studied 326 SMEs. By using multiple linear regressions as the analytical method this research found that the independent variables are funding and working capital policies that justify the initial hypothesis, which jointly states that funding policy and working capital variables have a positive and significant effect on the financial performance of SMEs in Donggala. Some suggestions are provided to strengthen those SMEs.

Keywords: Funding policy, working capital, financial performance, SMEs, Empirical Evidence

\section{Introduction}

Empowerment on SME cannot be separated from the basic conception of SMEs growth development. Designing a basic conception of SMEs empowerment is to build a system which capable of eliminating all the problems concerning the success of SME. One of the aspect that determine the success of SMEs is the business climate. This aspect is closely related to the ability of business systems built, which is associated with many actors and with many variables that significant in long-term period (multi-year). To determine the condition of each factors and actors that play a role-in, it needs to be evaluated every time, every location and each sector of business activities on SMEs

Through regional autonomy, every region in Indonesia is required to be able to develop any local potential they have in order to survive and thrive in the midst of regional and global competition. Implicitly, this means economic development of an area leads to more results-oriented approach to the development of local resources which are endogenous factors optimally.

To meet the challenges of global competition, local economic development needs to be directed to support the development of economic sectors that could potentially creating vast employment opportunities and have good prospects in improving the welfare of society in a region.

Great role of SMEs in economic development in Donggala is mainly because this sector absorbs quite a lot of resources which if exploited proportionally will be able to provide a multiplier effect that encourages the development of regions in Donggala significantly. The multiplier effect of SME sector is mainly derived from the vast number of business units as well as outstanding contributions to the creation of employment and sources of income, especially in rural areas and for rural households.

To create these SMEs as a sector with a competitive advantage necessarily to understand the limitations of SMEs on which in terms of size and funding policy and the ability of working capital, this may result in lower production capabilities and financial performance as a whole. When talking about the problems of the development of SME units in Donggala, issues of human capital constraints, knowledge and production technology have not been widely discussed urgently. It is most often expressed is the limitations of physical capital (financial management, and infrastructure) as well as difficulties in marketing method

The more visible phenomenon, in term of the development of SMEs from period to period in Donggala such are the 
lack of funding policy support, lack of working capital which directly affect the weak of production capabilities and comprehensive impact on the lack of financial performances of SMEs.

The phenomenon can be explained further by the condition of SMEs in Donggala, such: First, the financial condition indicated the poor ability in term of internal equity (own capital) thus most SMEs are still difficulties to cover their operational costs. Secondly, working capital remains a constraint where some of SMEs's working capital, including cash, accounts receivable and inventory are still relatively weak in reasons of frequently delays in the collection of accounts receivable and slow inventory turnover. Third, production capacity is a major constraint on SMEs because it is considered still contains many weaknesses mainly on the feasibility of production development, reliability of machinery, technical understanding of production, product quality, price and maintenance procedures. Fourth, financial performance indicated on profit, investments, assets and sales are still considered low

District authority of Donggala does not optimal yet in regard to the potential of SMEs to be developed not only in the provision of capital assistance but also on policy aspects of financing and working capital, hence those SMEs have not been able to expose its performance, especially in the financial aspect.

\section{Leverage Policy and Financial Performance Theory}

Funding policy is a policy that addresses sources of funds to finance a worthy investment. Withdrawal problem is considered attractive because all the used funds must have a cost that is often called cost of funds. At the time of using funds derived from loan, it is clear that the fund has a cost which is at least equal to interest rate, but at the time we use own capital (equity capital) we still have to consider the opportunity cost.

Myers (1984), Myers and Majluf (1984), stated that the company has a tendency to make choices about funding sources, called the policy of internal equity, if internal equity is insufficient then external finance will be considered. The use of external finance itself at first use as debt, if the debt is insufficient then the company uses external equity. Internal equity derived from the retained earnings where it is better source of funding than debt because it has no risk. There are some afffecting factors on funding policy (Leverage) as below:

\subsection{Sales Growth Rate}

For companies with high sales and earnings growth rates are tend to use more debt as a source of external funds than the firms that have the low level of sales growth.

\subsection{Stability Sales}

The more stable the sale of a company, the more likely the company finances its activities with debt. Because of the stability of sales will affect the stability of income.

\subsection{Structure Assets}

If the composition of company's asset is capital intensive, the main priority is equity-financing. Which mean that the loan capital is only a complement to it, especially to meet the funding requirements for working capital, See Gitman and Zutter, (2012)

\subsection{Deviden Policy}

Dividend policy is a decision on whether earnings will be distributed to shareholders or retained for future investments. Thus the optimal dividend policy is creating a balance between current dividend and growth in the future so as to maximize the company's value.

\subsection{Management attitude}

The attitude of management will have a direct influences in the decision making regarding the fulfillment of funding requirements. A manager who is optimistic with a clear vision about future, who have the courage to bear the substantial risk financing sales growth with debt from loan eventhough this kind of method contains fixed financial burdens. 


\subsection{Profitability}

Companies with a high rate of return tend to use a relatively small proportion of the debt, due to the high rate of return that funding requirements can be obtained from retained earnings. Some research evidence (Baskin, 1989, Titman and Wessels, 1988, Thies and Klock 1992) show that companies with a level of high returns on investments using debt relatively small.

\subsection{Magnitude Company}

A large company where the shares are so widespread, every expansion of the share capital would have little effect on the possibility of loss or shifting the control of the dominant party in the company. On the other side, a small company where the shares distributed only in a small scope, increasing the number of shares will have a significant influence on the possibility disappearance of the dominant party control in the company.

\subsection{Business and Bankruptcy risks}

In the company, business risk increases when using high debt. It also increases the risk of bankruptcy. Business risk is indicated by the variability of income earned in the future. This research shows that companies with a high risk should use less debt, to avoid the possibility of bankruptcy (Thies and Klock, 1992, Titman and Wessels 1988).

\subsection{Company Goals}

If the purpose of managers is to maximize prosperity/wealth of the shareholders then the optimal capital structure is to maximizes the value of the company. If the purpose of the managers to maximize job security, then the optimal capital structure lies on the average leverage of other companies in an industry.

\subsection{Centre Ownership and Control of Sound}

If the shares in the company owned only by a small number of owners, the managers will be reluctant to issuing new shares.

\subsection{Inflation Rate Estimation}

Long-term debt can use "Loan" term which negotiated from financial institutions or through issuing bonds. The process of bond sales quite similar as the sale of shares, which generally use an investment bank services. Long-term debt of a company usually have a maturity between 5 to 20 years.

For characteristic of firm related to financial source we can explore more Makoni, P.L. and Ngcobo, L. (2014) which found that it was easier for older, foreignowned firms in Zimbabwe to access bank credit because they had the capacity, collateral and performance trade record to support their applications

\section{Working Capital: A Review}

Working Capital or Net Working Capital is "the difference between current assets less current liabilities" (Arnold, 2008). From this definition we can observe some concepts, they are:

- Quantitative Concept: This concept is based on the quantity of funds that are embedded in the elements of current assets where if the assets once circled then it will be back in the initial form or assets in which funds that are embedded in it and will be free again within a short time. Thus the working capital according to this concept is total of current assets. Working capital in this definition is often called gross working capital

- Qualitative Concept: In this qualitative concept definition of working capital is also associated with the large amount of current debt or debt that must be paid immediately. Thus, the portion of current assets should be available to meet the immediate financial obligations which some part of the current assets should not be used to finance operational activities to preserve liquidity. Therefore, the working capital according to this concept is part of the current assets can actually be used to finance the company's operations without disturbing liquidity, which is the excess of current assets over current debt. Working capital in this sense is often called Net 


\section{Working Capital.}

- Functional Concept : This concept is based on the functions of fund in generating income. Any funds that are used in the company aims to generate revenue. There are some funds which used in a particular accounting period that entirely generate revenue in that period (Current Income) and the other funds that are not used. Most of the funds were intended to generate revenue for subsequent periods (Future Income).

The financial performance is the result of many decisions made continuously by management. Therefore, to assess the financial performance of a company needs to involve the analysis of cumulative financial and economic impact to the decision and consider it using comparative measure. In discussing the assessment method of financial performance, the company should be based on the published financial data and made in accordance with the applicable financial accounting principles generally. Reports such as this involves the most common data which are available for the purpose, although often do not represent the results and economic conditions.

Vickery et. al. (Anshori, 1999) using financial ratios such are: return on assets (ROA), return on investment (ROI) and return on sales (ROS) as an indicator of business performance.

The financial performance of a company or cooperative can be measured by financial ratios with liquidity ratio analysis, activity ratio, leverage ratio and profitability ratio. The greater the value of these ratios, the performance can be achieved. Whereas for the leverage ratio if the smaller the value, the better its performance will be.

According to Eugene and Michael (2005), Profitability, One observes that firms with very high rates of return on investment relatively use little debt. Although there is no theoretical justification for this fact, one practical example for this explanation is Intel as a very profitable firm.

To give clearer objective, this research working under the framework which can be seen as follow:
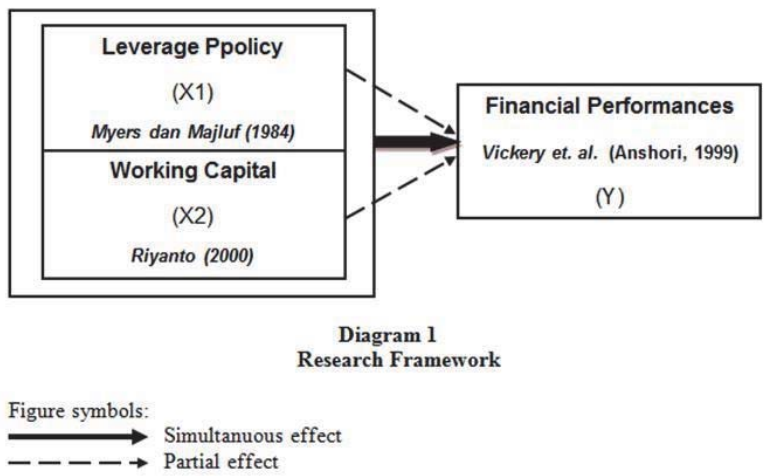

\section{Research Methodology}

Respondents of this study are business scale entrepreneurs who are still classified as micro, small and medium in trading sector, small industries and businesses services in the research area 16 districts in Donggala. In obtaining an accurate data through secondary and primary data, this study conducted for five months. This study determines the object influenced by funding and working capital policies on the financial performance of SMEs in Donggala district.

Observation is data collection through direct surveillance to the number of micro entrepreneurs, small and medium enterprises in each districts and villages. Conducting interviews with entrepreneurs especially SMEs about the type of business they do, loan and production capacity. Distributing questionnaires to MSMEs, to determine their perceptions of financial management and the success they earned. The study population was all entrepreneurs in Donggala with total 1,752 MSMEs spread throughout the district in the area of Donggala.

Determination of sample size in this study is using Taro Yamane formula or Slovin formulation followed by proportional allocation in each sub-district. Calculation of the sample size by setting precision 5 percent $(0.05)$. Result of sample calculation is:

$\mathrm{N}$ 1752

$$
n=0326 \text { SMEs }
$$

Further will be allocated proportionally to each district and village 
Respondents of this study were SMEs which are classified as business owners or executives of SMEs, which generally use borrowed funds and production process has been relatively full capacity.

\section{Operational Variabels Definition}

a. Independent Variable (X):

- The funding policy is a policy that describes the acquisition of sources both internal and external funds that will used to finance a potential investment.

- Working capital is the ability of SME funds to cover operational cost which consist of cash, accounts receivable and inventory

b. Dependent Variable $(\mathrm{Y})$ : Financial performance is a picture of the real situation regarding results achieved by SMEs on financial aspects (financial) measured through ROI, ROA and ROS

c. Variable measurements, carried out using the perception data as measured by the Likert's (ordinal) both independent and dependent variables

d. Especially for tabulation of quantitative data in this study will use the scale ratio measurement

e. Operationalization Variable Matrix. The Independent and dependent variables will be operational references in the research instruments preparation. Operationalization Variable Matrix described in Table 1 as follows:

Tabel 1. Operationalization Variable Matrix

\begin{tabular}{|c|c|c|c|c|}
\hline No & Variable & Dimension & Indicator & \begin{tabular}{|l|} 
Scale \\
\end{tabular} \\
\hline 1 & \begin{tabular}{|l|} 
Leverage Policy \\
Myers dan Majluf (1984)
\end{tabular} & $\begin{array}{l}\text { Internal Equity } \\
\text { External Finance }\end{array}$ & \begin{tabular}{|l|} 
Current Earning \\
Retain Earning \\
Short Term Liabilities \\
Long Term Liabilities
\end{tabular} & Ordinal \\
\hline 2 & $\begin{array}{l}\text { Working Capital } \\
\text { Riyanto (2000) }\end{array}$ & $\begin{array}{l}\text { 1. Cash } \\
\text { 2. Account Receivable } \\
\text { 3. Inventory }\end{array}$ & $\begin{array}{l}\text { 1. Cash Availability } \\
\text { 2. Ability of cash to pay Short Term Liabilities } \\
\text { 3. Cash Excess } \\
\text { 1. Receivable Turnover } \\
\text { 2. Receivable Amount } \\
\text { 3. Receivable Risks } \\
\text { 1. Inventory Adequacy } \\
\text { 2. Inventory Computation } \\
\text { 3. Computation of ending inventory }\end{array}$ & Ordinal \\
\hline 3 & \begin{tabular}{|l|} 
Kinerja Keuangan \\
Vickery et.al. (Anshori, 1999)
\end{tabular} & $\begin{array}{l}\text { 1. Return on invesment (ROI) } \\
\text { 2. Return on Aset (ROA) } \\
\text { 3. Return on Sales (ROS) }\end{array}$ & $\begin{array}{l}\text { 1. Earning before interest } \& \text { tax } \\
\text { 2. Investment } \\
\text { 1. } \quad \text { Earning after interest \& tax } \\
\text { 2. } \quad \text { Assets } \\
\text { 1. } \\
\text { 2. } \\
\text { 2. Sarning before interest } \& \text { tax }\end{array}$ & Ordinal \\
\hline
\end{tabular}

\section{Research Instrument and Analyzis Data Technique}

There are two important conditions that apply in the questionnaire, which are must valid and reliable. A questionnaire is said to be valid if statements on the questionnaire are able to express something that will be measured by the questionnaire itself. While a questionnaire is said to be reliable if the corresppondence answered consistently or stable over time.

\subsection{Validity Test}

Validity is a test to measure how far the instruments can be measured. Validity test scores obtained from correlating every item with the total score (corrected item-total Correlation). These total correlation results is to determine significance the item against the factor, where the items that have a positive correlation above the critical $r$ value table (0.30) indicates that the item is valid. (Sugiyono; 2004: 24).

In this study, the used validity is the internal validity. Internal validity is achieved when suitability arise between part of instruments as a whole. 


\subsection{Reliability Test}

The research instruments beside valid, must also be reliable (reliable). Instruments can be said to be reliable if the instrument produces result that are consistent, so this instrument can be used safely as it can work well at different times with different conditions, in another word means that reliability measurement can give same results when measuring back the same object. (Sugiyono, 2002: 110)

In this research, internal consistency reliability test using Cronbach's alpha coefficient (a). An instrument called reliable if croncbach alpha greater than 0.60. (Nunnally in Zeithami, Berry \& Parasuraman, 1996: 7)

Technical analysis of the data used is in the form of linear regression. This form is used because theoretically the studied dependent variable $(Y)$ have a tendency linear relationship with each of the independent variables $(X)$. Furthermore, in order the model can be operationalized by Ordinary lease Square (OLS), then it must be fulfilled classical assumptions.

The model was used to analyze the influence of independent variables (X1, and $X 2)$ to the variable $(Y)$. After the hypothesis tested at the $\mathrm{F}$ test and $\mathrm{t}$ test. Specification of a reference model in this study is multiple regression formula for the population. (Soeprihanto and John; 2001: 26) as follows:

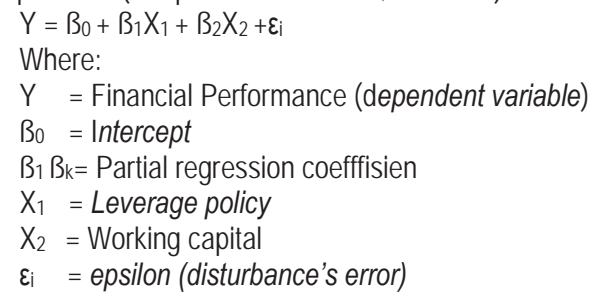

To be able to use multiple linear regression analyzis, it is a must to meet these classical assumptions as follows:

1. Multicolinearity test

2. Heteroskidastity test

3. Normality Test

\section{Result Analysis}

\subsection{Multiple Linear Regression Analysis}

In multiple regression analysis, most are going to discuss about the correlation coefficient, determination coefficient, regression, regression coefficients, and also the partial correlation coefficients for the regression involving more than one independent variable.

The obtained data from the results of field research, then analyzed using qualitative and quantitative analysis, which used quantitative analysis to prove the hypothesis by using multiple linear regression analysis, while qualitative analysis itself is used to explain the evidence of quantitative analysis

Verification with quantitative analysis is intended to test a variation of the tool multiple linear regression models which were used to describe the independent variable $(X)$ on the dependent variable $(Y)$ by testing the significance of the regression coefficients. Calculation results with the regression model obtained by regression coefficient, as seen in table 2 as follows:

Tabel 2. Multiple Regression Linear Result

\begin{tabular}{|c|c|c|c|c|c|c|}
\hline \multicolumn{7}{|c|}{ Dependent Variabel $\mathrm{Y}=$ Financial performances } \\
\hline Variabel & Reg. Coeff & Std. Error & Beta & t- hitung & t- table & Sig \\
\hline $\mathrm{C}=$ Constant & 1.375 & 0.170 & & 8.078 & & 0.000 \\
\hline X1 = Leverage Policy & 0.315 & 0.038 & 0.411 & 8.195 & 1.970 & 0.000 \\
\hline X2 = Working capital & 0.314 & & 0.305 & 6.085 & 1.970 & 0.000 \\
\hline $\begin{array}{ll}\text { Multiple-R } & =0 \\
\text { R-Square } & =0 \\
\text { Adjusted R Square } & =0\end{array}$ & $\begin{array}{ll}22 & \text { F sta } \\
387 & \text { Sig F } \\
83 & \text { F-tab }\end{array}$ & $\begin{array}{l}\text { tic }=101,99 \\
=0,000 \\
=3,36\end{array}$ & & & & \\
\hline Durbin-Waston $=1$ & & & & & & \\
\hline
\end{tabular}

Source: Author's Own 
Based on the calculation results as shown in table 2 above, the regression equation is expressed as follows:

$$
\mathrm{Y}=1,375+0,315(\mathrm{X} 1)+0,314(\mathrm{X} 2)
$$

In the equation of multiple linear regression model, the value of regression coefficient independent variable $(X)$ is the leverage policy (X1) and working capital (X2) have positive effects. Coefficient independent variable is positive means if there is a change in the independent variable $(X)$ will causes a change in the direction of the dependent variable $(Y)$ which is the financial performance and vice versa. In other words, the financial performance variable $(Y)$ equal to 1,375 indicates that if the funding policy variables (X1) and working capital (X2) equal to zero, then the financial performance (Y) equals to 1,375 or the constant value is 1.375

Correlation coefficient of 0.622 shows a moderate correlation between leverage policy variabel (X1) and working capital (X2), on the financial performance variable (Y) with intervals coefisien 0,60 - 0.699 (Sugiyono, 2004). Similarly, the $\mathrm{R}$ Square (coefficient) of 0,387 indicates that $38.7 \%$ of financial performance depends on the leverage policy (X1) and working capital (X2), so that there are $61.3 \%$ of other variables that are not explained or other words that some of financial performance variables are not identified in the study, such are: the ability of production, marketing communications, business partnership SMEs, product development, and work productivity.

\subsection{Hypothesis Verification}

\subsubsection{Hypothesis verification (F test)}

F test analysis conducted for the purpose of proving the hypothesis that leverage policy (X1) and working capital (X2), simultaneously have significant effect on the financial performance of SMEs in Donggala

$F$ statistical test (simultaneous significance test), basically indicates whether all independent variables $(X)$ are included in the model have a positive influence together with the dependent variable $(\mathrm{Y})$. $\mathrm{F}$ test is done by comparing the probability value against the value of alpha $(a)=0.05$. $F$ test also has a significant influence when the probability value (sig) is smaller than the value of alpha $(P<0.05)$.

From the calculation results obtained by using analysis of regression model, $F_{\text {count }}$ equal to 101.996 with a probability level of 0.000 (significant). With a probability value is much smaller than 0.05 , then it indicates that the funding policy variables (X1) and working capital (X2), simultaneously have significant effect on the financial performance variable (Y) SMEs in Donggala, or it can be said that the first hypothesis of this study is accepted (true).

\subsubsection{Hypothesis verification Partial (t test)}

To answer the hypotheses about the effect of each variable will be done by using the $t_{\text {test, }}$ testing this partial effect is intended to determine whether is there any influences of independent variables $(X)$ which are leverage policy (X1) and working capital $(\mathrm{X} 2)$ to the dependent variable $(\mathrm{Y})$ namely financial performance.

$T_{\text {test }}$ was performed to test the significance of regression coefficient (B) partially, by comparing the value of probability with the value of alpha $(a)=0.05$, test will have a significant effect if the result $P<0.05$, furthermore to know more how the influence of each independent variables to the dependent variable, declared as follows:

- First hypothesis verification; Variable of Leverage Policy (X1) partially effect on financial performance of SMEs

tcount $\mathrm{X} 1=8.195$ at the level of error (alpha) of $5 \%$ or regression coefficient $0.05>0.000$, it is indicate that the leverage policy (X1) partially has a positive and significant impact on the financial performance variable $(Y)$ on SMEs in the District Donggala, thus it can be stated that the second hypothesis of this study is accepted (true).

- Second hypothesis verification; Working Capital Variable (X2) partially effect on financial performance of SMEs (Y)

$\mathrm{T}_{\text {count }} \mathrm{X} 2=6,085$ with standard of error (alpha) of $5 \%$ or regression coefficient $0.05>0.000$. It is indicate that the variable working capital (X2) partially has a positive and significant impacts on the financial performance variable $(Y)$ on SMEs in Donggala, so that the third hypothesis is also accepted (true). 


\section{Discussion of Empirical Result}

\subsection{Simultaneous Effect of Leverage Policy and Working Capital variables on Financial Performance of SMEs}

$F$ test is used to determine the significance of the used regression model. By means is to compare the $F_{\text {count }}$ with the $F_{\text {table }}$ at significance level (a) of $5 \%$. From the processed data obtained $F_{\text {count }}=101.996$, while $F_{\text {table }}$ at significance level (alpha) of $5 \%$ by df $(2 ; 232)$ is approximately 3.036 . Due to Fhitung $>F_{\text {table }}(101.996>3.036)$, which means that the regression model on the effect of leverage policy and working capital on the financial performance is fit or suitable. This shows that the leverage policy and working capital together affect the financial performance of SMEs in Donggala

This condition shows that companies are basically need capital all the time, both working capital and fixed capital. Working capital is very important to smooth the operation and other short-term nature for working capital which will always cycled as long as the business still run and working capital can be used to maintain the company's performance in this case of SMEs.

Working capital management is usually meant as organization of current assets such are cash, marketable securities, accounts receivable and inventory, and organize the current or short-term debt. Current asset shows the amount of money owned and assets that have been converted into money. It is often said that every asset has different levels of liquidity. Cash itself is the most liquid asset. While other assets, liquidity has two dimensions, namely time period to turn into cash and level of certainty associated with the change ratio, or price of the asset. The amount of investment in current asset will affect the value of company.

Leverage policy is the company ability to pay its obligations in the future, that thing will be respond positively by the market. There are two views on leverage decisions. The first is known as the traditional view that states that the capital structure affect the value of the company.

The second view is the thing that must be considered in optimizing the value of the company is dividend policy in which the investor has the main goal to improve the welfare by expect return in the form of dividends and capital gains, whereas the company expects continuous growth to maintain their life as well as providing welfare to its shareholders, so that the dividend policy is important to meet the expectations of shareholders in term of dividends by not hamper the company's growth on the other side.

The results showed that the leverage policy and working capital variables turn out to have simultaneous and significant influence on the financial performance of SMEs in Donggala.

\subsection{The Influences of Leverage policy on Financial Performance of SME}

Result of the second test hypothesis by test obtained value of $t=8.195$ and received at the significance level of $5 \%(0.000$ $<0.05$ ). It indicates a positive and significant influence on the leverage policy.

Verification result on hyphotesis above is supported by theories related to leverage policy proposed by Brigham (1997). He stated that in developing the capital structure targets should do analysis from many factors with taken into consideration of the company's financial condition. SME's leveraging policy in accessing external capital (loan capital) will increase the capital structure of those SMEs. Capital structure policy is reflected in the magnitude of debt ratio. Furthermore, Ang (1997) suggests that the higher the DER will affect the profit (return on equity) achieved by the company.

Verification result on hypothesis is also supported by previous studies proposed by Sugihen (2003), which examines the effect on productivity of Capital Structure and Performance of Financial Assets and Value of Open Manufacture Industry in Indonesia. Based on the research conclusion, it can be concluded that the ability of financial management in determining the target capital structure (financing activities), capabilities of investment management to enable the use of assets (investment activity) and capabilities of management operations in production and distribution process (operating activities).

\section{Effect of Working Capital on Financial Performance of SMEs}

Result of the third hypothesis test using test gain value at $t=6.085$ with significance level of $5 \%(0.000<0.05)$. It means the working capital have positive and significant impact on the financial performance of SMEs.

The proven hypothesis is supported by theories related to funding policy, proposed by Weston (1992) where traditionally the first category in the measure of performance is the analysis of the future cash flows begins with an analysis of profitability. In essence, effective and efficient working capital management will greatly affect the financial 
position of the company that will led primarily improve on the financial performance.

The Results above also supported by previous studies proposed by Pieter Leunupun (2003). He conducted a research on profitability and some factors that influence on it (studies on several KUD in Ambon city). The independent variables were profit margin, investment turnover, equity multiplier, while the dependent variable is profitability of equity (ROE). The method used was linear regression to estimate or test the hypothesis theoretically. Result of the study has a positive direction for each group KUD.

Martono (2002), conducted a research on the analysis of the effect of industry profitability, weighted financial leverage ratios and weighted capital investment as well as the market share towards "ROA and ROE" on go public manufacturing companies in Indonesia. Independent variables were used industrial profitability, leverage ratio, weighted ratio of capital intensity, and market share, while the dependent variables were ROE and ROA. The method used in the study was multiple regression analysis. The result says that industry profitability variable significantly affect positively to ROA, while industry profitability and market share have significant positive effect on ROE. Meanwhile, leverage ratio variable, weighted capital variable, weighted intensity capital ratio has significant negative effect on ROA and other variables have no significant effect on ROA. And the weighted leverage ratio has significant negative effect on ROE, while other variables have no significant effect on ROE. The newest research on leverage ratio and firm capabilities see also R. Srinivasan (2014)

\section{Conclusion and Suggestion}

Based on the simultaneous results that the independent variables namely leverage and working capital policies are to justify the first hypothesis states that leverage policy variable simultaneously with working capital policy have positive and significant effects on the financial performance of SMEs in Donggala.

- $\quad$ On the leverage policy for SMEs, they shall consider the use of retained earnings in purpose to cover the need of working capital, operational costs, purchase of production equipment and also to anticipate the emergence of unexpected costs

- The obstacle of SMEs to access the financial institutions such banks and non-banks to strengthen their working capital is the difficulty to meet the requirements, such as legal administrative paper for SMEs, feasibility, business proposals and the financial statement. Thus, this paper advises in particular to local governments to facilitate SMEs in the form of training and coaching related to the weaknesses they faced.

- SMEs are advised to pay more attention at availability of cash to meet operational costs such as payroll, purchase inventory, fixed assets, immediate due debt payments include interest. SMEs also have to consider the availability of cash in the ideal limit to avoid empty cash. SMEs need to strengthen the collection of accounts receivable, lending only to people you trust, avoiding excessive sales transaction and operational cost.

\section{References}

Alada Ara, Ajayi FF, Alaka OO, Akande OO. 2011. Gastric acid secretion and experimental ulceration in rats fed soybean diet preparations. Afr J Biomed Res. Hal ;8:203-5.

Ang, Robbert. 1997. "Buku Pintar: Pasar Modal Indonesia (The IntelligentGuide to Indonesian Capital Market)". Mediasoft Indonesia

Anshori, Musslich. 1999. Pengaruh kemampuan Produksi, kemampuan Pemasaran dan Strategi Bisnis Terhadap Kinerja Bisnis Pada Perusahaan Manufactur di Indonesia, Disertasi S-3, PPS Unair, Surabaya.

Bambang Riyanto, 2001, Dasar-Dasar Pembelanjaan Perusahaan, Edisi Keempat, Cetakan Ketujuh, Yogyakarta: BPFE.

Baskin, J., 1989, "Dividend Policy and the Volatility of Common Stock", Journal of Portfolio Management, 15(3): 19-25.Brigham, Eugene F., dan J. Fred Weston, 1990, Financial Management: Theory. and Practice, Sixth Edition, The Dryden Press, New York

Brigham, E. and Gapenski, L. 1997. Financial Management Theory and Practice, 8th ed. The Dryden Press, Fort Worth TX p. 48, 856857 Business World Top 1000 Corporations in the Philippines. 2009. Vol 24, Business World Publishing Corporation, Quezon City, Philippines.

Brigham, Eugene F, and Joel F. Houston, 2001. Fundamental of Financial Management, Alih Bahasa Dodo Suharto dan Herman Wibowo, Manajemen Keuangan, Edisi Kedelapan, Buku Satu, Erlangga, Jakarta.

2001. Fundamental of Financial Management, Alih Bahasa Dodo Suharto dan Herman Wibowo, Manajemen Keuangan, Edisi Kedelapan, Buku Dua, Erlangga, Jakarta.

Eugene F.B \& Michael C. E. 2005. Financial Management. South-Western,Part of the thomson corporation.

Eugene F. Brigham \& Louis C.Gapenski, 1983, Intermediate FinancialManagement, Fifth edition-International edition, The Dryden Press.

Fahmi, Irham. 2006. "Manajemen Kinerja Teori dan Aplikasi", Bandung : Alfabeta.

Ghozali, Imam, 2001. Aplikasi Analisis Multivariate Dengan Program SPSS, Badan Penerbit Universitas Diponegoro, Semarang. 
Gitman, L.J. and Zutter, C.J. (2012). Princples of Managerial Finance, 13th ed. Essex: Pearson.

Gujarati, Damodar N., 1995, Basic Econometrics, Third Edition, International Edition, McGraw Hill International.

Jumingan, 2006. Analisis Laporan Keuangan, Cetakan Pertama, PT Bumi Aksara, Jakarta.

Kementerian Negara Koperasi dan UMKM, (2003). Seri Kebijakan: Pengembangan Sentra UMKM, BDS dan MAP, (2003). Kementerian Koperasi dan UMKM.Jakarta.

Keputusan Menteri Keuangan Nomor 40/KMK 06/2003 tentang Pendanaan Kredit Usaha Mikro dan Kecil.

Leunupun, Pieter, 2003. Profitabilitas Ekuitas dan Beberapa Faktor Yang Mempengaruhinya. Maluku: Universitas Petra.

Makoni, P.L. and Ngcobo, L. (2014). Finance and Firm Characteristics in Zimbabwe, Journal of Corporate Ownership and Control, 11 (2), pp. 465-472

Martono, Cyrillius, 2002."Analisis Pengaruh Profitabilitas industri, rasioLeverage Keuangan Tertimbang dan Intensitas Modal Tertimbang Serta Pangsa Pasar Terhadap ROA dan ROE Perusahaan Manufaktur Yang Go Publik di Indonesia," Jurnal Akuntansi dan Keuangan, Vol,4, No.2, November, 2002, pp.126-140.

Martono, 2002. Manajemen Keuangan, Yogyakarta: Ekonisia.

Martono \& Agus Harjito. 2001. Manajemen Keuangan. Edisi 1, Ekonisia, Yogyakarta. 2002. Bank dan Lembaga Keuangan Lain. Yogyakarta: Ekonisia.

Moeheriono. 2009. Pengkuran Kinerja Berbasis Kompetensi. Bogor: Ghalia Indonesia.

Mulyadi. 1997. Akuntansi Manajemen Keuangan (Konsep, Manfaat dan Rekayasa). Edisi Kedua, Bagian Penerbitan Sekolah Tinggi Ilmu Ekonomi. YKPN. Yogyakarta.

Munawir, 2000. Analisis Laporan Keuangan. Liberty, Yogyakarta. 2002. Analisa Laporan Keuangan,Edisi Keempat. Yogyakarta :Liberty Yogyakarta.

Myers, S. C. 1984. The Capital Structure Puzzle, The Journal of Finance,XXXIX(3), 575-592.

Myers, S. C. and Majluf, N. S. 1984. Corporate Financing and Investment Decisions When Firms Have Information that Investors Do not Have, The Journal of FinancialEconomics, 13, 187-221.

Nazir, M, Sajid and Afza, Talat(2009)," Impact of Aggressive Working Capital Management Policy on Firms' Profitability", The IUP Journal of Applied Finance, Vol. 15, No. 8, pp.19-30.

Sawir, 2005. Analisis Kinerja Keuangan dan Perencanaan Keuangan Perusahaan. PT Gramedia Pustaka, Jakarta.

Sartono, Agus. 1995. Manajemen Keuangan: Teori dan Aplikasi. Yogyakarta: BPFE.

Sekaran, Uma, 2003, Metodologi Penelitian untuk Bisnis, edisi empat, Salemba Empat, Jakarta.

Singarimbun M., dan Efendi S., 1995 Metode Penelitian Survay, LP3ES Jakarta.

Sugiyono, 1999, Metode Penelitian Bisnis, Cetakan Keenam, Alfabeta, Bandung.

Sugihen, Syafruddin Ginting. 2003. Pengaruh Struktur Modal Terhadap Produktivitas Aktiva dan Kinerja Keuangan serta Nilai Perusahaan Industri Manufaktur Terbuka Di Indonesia, Disertasi Program Pascasarjana Universitas Airlangga, Surabaya.

Sucipto 2003. Penilaian Kinerja Keuangan.Digitized by USU digital library.

Soeprihanto, John. 2001. Statistik: Teori dan Aplikasi. Edisi Keenam Jilid 2. Jakarta: Erlangga.

Srinivasan, R., 2014, The management consulting industry: Growth of consulting services in India: Panel discussion, IIMB Management Review, Volume 26, Issue 4, December 2014, Pages 257-270

Sundjaja dan Barlian, 2003, Manajemen Keuangan Dua, Edisi Keempat, Literata Lintas Media, Jakarta.

Sundjaja, Ridwan, S \& Inge, Barlian. 2003. Manajemen Keuangan Satu, Edisi Kelima, : PT. Prehallindo. Jakarta.

Sutrisno. 2009. Manajemen Keuangan teori, Konsep dan Aplikasi, Edisi pertama, Cetakan ketujuh, Ekonisia Yogyakarta.

Thies, C. F. and Klock, M. S. 1992 . Determinants of Capital Structure, Review of Financial Economics, 1(2), 40-53.

Tim penyusun Kamus Pusat Pembinaan dan Pengembangan Bahasa. 1997. (Edisi kedua). Jakarta: Penerbit Balai Pustaka.

Titman, S. and Wessels, R. 1988. The Determinants of Capital Structure Choice, The Journal of Finance, XLIII, 1, 1-19.

Vickery, K, Shawnee, 1991, A Theory of Production Competence Revisited, Comment and Notes, Decision Science, Vol 22.P.635

Weston, J. Fred, dan Thomas Copeland, 1987. Manajemen Keuangan, Jilid 1, Edisi 8. Diterjemahkan oleh A. Jaka Wasana dan Kir Iranoko, Jakarta: Erlangga.

1992, Manajemen Keuangan Edisi Kedelapan (Edisi revisi), Penebit Binarupa Aksara, Jakarta.

Weston, Fred J and Brigham, F, Eugene.1993. Dasar-Dasar ManajemenPerusahaan. (Edisi kesembilan). Jilid I. Penerbit Erlangga. Wilson, James D dan Campbell, John B. 1990. Controllership. Tugas akuntan manajemen. (Edisi ketiga). Jakarta: Penerbit Erlangga. Yamane, Taro. 1990. Statistics an Introductory Analysis 2nd edition. New York, Harper and Publisher.

Zeithami dkk, 1996, The Behavioral Cosequences of Services Quality, Journal of Marketing, Vol. 60 (April) p 31-46. 